\title{
Penerapan Metode K-Means Untuk Menganalisis Minat Nasabah Asuransi
}

\author{
Juniar Hutagalung*, Fifin Sonata \\ Prodi Sistem Informasi, STMIK Triguna Dharma, Medan, Indonesia \\ Email: ${ }^{1, *}$ juniarhutagalung991@email.com, ${ }^{2}$ fifinsonata2012@gmail.com \\ Email Penulis Korespondensi: juniarhutagalung991@email.com
}

\begin{abstract}
Abstrak-Asuransi merupakan mekanisme proteksi atau perlindungan dari resiko kerugian dengan cara mengalihkan resiko pada pihak lain. Adakalanya produk yang baru saja muncul menjadi produk yang lebih unggul dalam hal penjualan, sehingga peminatan suatu produk tidak mutlak diukur dari tahun produk tersebut dirilis. Faktor kendalanya diantaranya dari sisi pemasaran produk saat diluncurkan. Penawaran produk-produk dengan premi murah disertai benefit sesuai yang diinginkan nasabah. Namun perusahaan asuransi masih kesulitan dalam hal mengelompokkan produk-produk unggulan yang banyak diminati calon nasabah. Untuk itu diperlukan teknik mengelompokan produk-produk asuransi agar memudahkan perusahaan melihat produk-produk unggulan dan memilih produk yang sesuai dengan kebutuhan nasabahnya. Melakukan analisis dan mengolah data dengan metode $K$-Means dalam klasterisasi produk asuransi merupakan tujuan penelitian ini. Penerapan algoritma $K$-Means ini untuk membantu perhitungan nilai kemurniannya dari hasil clustering yang dilakukan sehingga klasterisasi produk asuransi sesuai dengan kebutuhan nasabahnya. Penerapan metode $K$-Means dengan teknik clustering untuk data mining menghasilkan informasi produk asuransi yang lebih diminati para calon nasabah. Hal ini sangat tepat dalam melakukan pengelompokan jenis data karena lebih mudah dalam implementasi dan penerapannya dapat memfilter dengan cepat dan tepat. Perhitungan dengan metode K-Means dengan sampel data 55 nasabah diperoleh 3 cluster yaitu cluster 1 untuk asuransi kebakaran mempunyai jumlah nasabah sebanyak 30 orang, cluster 2 untuk asuransi kecelakaan 24 orang dan cluster 3 untuk asuransi kesehatan 1 orang.
\end{abstract}

Kata Kunci: Asuransi; Cluster; Datamining; K-Means; Premi

Abstract-Insurance is a mechanism of protection or protection from the risk of loss by transferring the risk to another party. Sometimes a product that has just emerged becomes a product that is superior in terms of sales, so that interest in a product is not absolutely measured from the year the product was released. The constraint factors include the marketing of the product when it was launched. Offering products with low premiums along with the benefits that customers want. However, insurance companies still have difficulty in classifying superior products that are in great demand by prospective customers. For this reason, a technique for grouping insurance products is needed to make it easier for companies to see superior products and choose products that suit the needs of their customers. Analyzing and processing data using the K-Means method in the clustering of insurance products is the aim of this study. The application of the K-Means algorithm is to help calculate the purity value from the results of the clustering carried out so that the clustering of insurance products is in accordance with the needs of its customers. The application of the K-Means method with clustering techniques for data mining produces information on insurance products that are more attractive to potential customers. This is very appropriate in grouping data types because it is easier to implement and its application can filter quickly and precisely. Calculations using the K-Means method with a data sample of 55 customers obtained 3 clusters, namely cluster 1 for fire insurance which has 30 customers, cluster 2 for accident insurance 24 people and cluster 3 for health insurance 1 person.

Keywords: Insurance; Cluster; Datamining; K-Means; Premi

\section{PENDAHULUAN}

Asuransi adalah lembaga ekonomi dengan tujuan mengurangi resiko, menggabungkan unit-unit yang mempunyai resiko sama atau hampir sama dalam jumlah memadai supaya probabilitasnya dapat diramalkan dan disalurkan ke unit yang mengalami resiko[1]. Asuransi merupakan mekanisme proteksi atau perlindungan dari resiko kerugian dengan cara mengalihkan resiko pada pihak lain. Asuransi atau pertanggungan adalah perjanjian antara dua pihak atau lebih, dengan mana pihak penanggung mengkaitkan diri kepada nasabah, dengan menerima premi asuransi, untuk memberikan penggantian kepada nasabah karena kerugian, kerusakan, atau kehilangan keuntungan yang diharapkan, atau tanggung jawab hukum kepada pihak ketiga. Manfaat asuransi diantaranya rasa aman dan perlindungan, pendistribusian biaya dan manfaat yang lebih adil, polis asuransi dapat dijadikan sebagai jaminan untuk memperoleh kredit, berfungsi sebagai tabungan dan sumber pendapatan, alat penyebaran resiko, membantu meningkatkan kegiatan usaha[2].

Kendala-kendala yang dialami perusahaan asuransi nasional adalah kurangnya edukasi dan awareness masyarakat tentang pentingnya asuransi. Adanya ketidakpercayaan terhadap proses klaim dan lamanya proses terbitnya polis asuransi. Oleh karena itu pemanfaatan analisis big data dapat membantu perusahaan menjadi lebih efisien dan meningkatkan kepuasan nasabah terhadap layanan perusahaan asuransi.

Kendala-kendala yang dialami perusahaan asuransi nasional adalah kurangnya edukasi dan awareness masyarakat tentang pentingnya asuransi. Adanya ketidakpercayaan terhadap proses klaim dan lamanya proses terbitnya polis asuransi. Oleh karena itu pemanfaatan analisis big data dapat membantu perusahaan menjadi lebih efisien dan meningkatkan kepuasan nasabah terhadap layanan perusahaan asuransi.

Tujuan utama dari penelitian ini menggunakan metode clustering adalah mengelompokkan sejumlah data/objek ke dalam suatu cluster sehingga cluster tersebut akan berisi data yang sama dengan masing-masing 
grup. Pada penelitian ini digunakan Algoritma Divisive Hierarchy untuk membentuk cluster. Pola yang diperoleh diharapkan dapat memberikan pengetahuan bagi perusahaan Media World Pekanbaru sebagai alat pendukung pengambilan kebijakan[9].

Obyek penelitian ini adalah Produk Asuransi Sinar Mas yaitu Asuransi Kebakaran, Asuransi Kecelakaan dan Asuransi Kesehatan. Untuk itu diperlukan teknik mengelompokan produk-produk asuransi agar memudahkan perusahaan melihat produk-produk unggulan dan memilih produk yang sesuai dengan kebutuhan nasabahnya. Melakukan analisis dan mengolah data dengan metode $K$-Means dalam klasterisasi produk asuransi merupakan tujuan penelitian ini. Penerapan algoritma $K$-Means ini untuk membantu perhitungan nilai kemurniannya dari hasil clustering yang dilakukan sehingga klasterisasi produk asuransi sesuai dengan kebutuhan nasabahnya.

Adakalanya produk yang baru saja muncul menjadi produk yang lebih unggul dalam hal penjualan, sehingga peminatan suatu produk tidak mutlak diukur dari tahun produk tersebut dirilis. Faktor kendalanya diantaranya dari sisi pemasaran produk saat diluncurkan. Penawaran produk-produk dengan premi murah disertai benefit sesuai yang diinginkan nasabah. Namun demikian perusahaan kerap kali masih kesulitan dalam hal mengelompokkan produk-produk unggulan yang banyak diminati calon nasabah.

Penelitian ini menggunakan data kuesioner penilaian nasabah pemegang polis terhadap produk Asuransi Kebakaran, Asuransi Kecelakaan dan Asuransi Kesehatan. Penerapan metode K-Means dengan teknik clustering untuk data mining akan menghasilkan informasi produk asuransi apa yang lebih diminati para calon nasabah. Hal ini sangat tepat dalam melakukan pengelompokan jenis data karena akan lebih mudah dalam implementasi dan penerapannya dapat memfilter dengan cepat dan tepat.

Berdasarkan penelitian sebelumnya bahwa hasil pengujian dengan record 454 data yang di lakukan. Metode algoritma K-Means dapat di terapkan untuk mengelompokan data nilai pertanggungan, premi dan klaim berdasarkan clustering dengan nilai terendah sedang dan tertinggi berdasarkan ketentuan perusahaan. Dengan pengelompokan sebanyak 3 cluster dimana memiliki batasan nilai yang berbeda[7]. Sistem ini telah berhasil menerapkan metode Profile Matching untuk pengambilan keputusan pemilihan produk asuransi jiwa perorangan bagi calon nasabah dengan studi kasus AJB Bumiputera 1912 Malang[8]. Perhitungan algoritma K-means menghasilkan jenis asuransi Mitra Beasiswa sebagai pilihan yang cukup tinggi untuk di minati para calon nasabah[4]. Prinsip data mining dilakukan agar dapat membangun sistem clustering portal jurnal internasional sebagai rekomendasi bagi peneliti untuk publikasi berdasarkan kualitas cluster menggunakan kernel k-means[5]. Hasil penelitian menyatakan bahwa status gizi balita dapat diklaster menggunakan metode $K$-Means melalui parameter berat badan menurut umur pada 4 klaster[6]. Penawaran dari perusahaan asuransi menjadi daya tarik bagi calon nasabah yang ingin menggunakan jasa asuransi diantaranya asuransi jiwa, kesehatan, kendaraan, properti/bangunan dan masih banyak lagi. Setiap calon nasabah menginginkan manfaat asuransi yang berbeda beda, tetapi dari produk asuransi yang dipilih masih banyak nasabah yang tidak mengerti manfaatnya. Akhirnya menyesal dan kecewa, sehingga nasabah menganggap asuransi itu tidak bermanfaat dan bahkan tidak melanjutkan pembayaran/berhenti ditengah jalan [3].

\section{METODOLOGI PENELITIAN}

\subsection{Tahapan Kerangka Kerja}

Penelitian ini perlu menyusun kerangka kerja yang berisi tahapan atau langkah-langkah dalam menyelesaikan permasalahan dalam mengelompokkan minat nasabah asuransi. Langkah-langkah penelitian yang dilaksanakan adalah sebagai berikut:

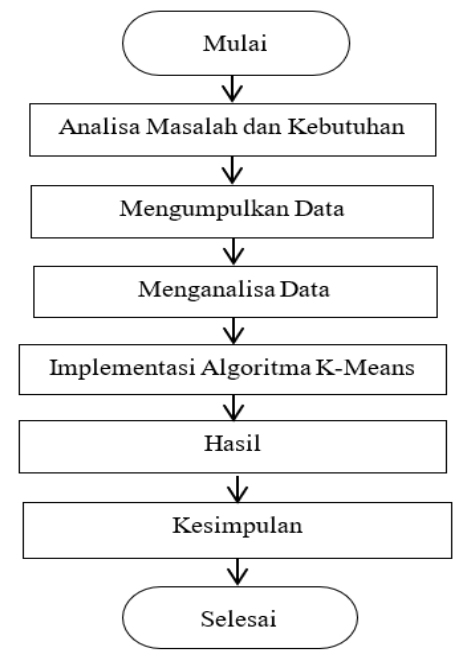

Gambar 1. Diagram Alir Penelitian 
Penjelasan gambar 1 pada diagram alir penelitian:

1. Analisa Masalah dan Kebutuhan

Pada fase ini akan ditentukan titik masalah sebenarnya dan elemen-elemen apa saja yang dibutuhkan untuk penyelesaian masalah dalam proses clustering produk-produk unggulan asuransi.

2. Mengumpulkan Data

Proses pengumpulan data dilakukan dengan studi kepustakaan dari beberapa referensi buku dan jurnal. Data penelitian diperoleh dengan menggunakan kuesioner yang diisi oleh nasabah peminat asuransi di PT Asuransi Sinar Mas.

3. Menganalisa Data

Data yang telah dikumpulkan kemudian dilakukan analisis data minat nasabah dalam pemilihan produk asuransi dengan menggunakan algoritma K-Means.

4. Implementasi Algoritma K-Means

Pada penelitian ini menggunakan Algoritma K-means untuk mencari solusi permasalahan penelitian. Pada tahap implementasi $K$-Means dilakukan proses perhintungan

5. Hasil dan Kesimpulan

Proses pengujian dilakukan untuk mengetahui apakah model yang dihasilkan valid dan sesuai dengan hasil perhitungan yang dilakukan. Kesimpulan yang diperoleh menghasilkan informasi produk asuransi apa saja yang lebih diminati para calon nasabah.

\subsection{Data Mining}

Dalam data mining terdapat metode-metode yang dapat digunakan seperti klasifikasi, clustering, regresi, seleksi variabel, dan analisis[10]. Data mining adalah suatu kegiatan analisa data untuk mencari suatu pola tertentu, dengan jumlah data yang besar dan bertujuan utuk menghasilkan informasi yang dapat digunakan dan dikembangkan lebih lanjut[11]. Data mining adalah metode untuk menemukan informasi baru yang berguna dari kumpulan data yang besar dan dapat membantu dalam pengambilan keputusan[12].

\subsection{Clustering}

Analisis cluster merupakan teknik analisa data yang bertujuan untuk mengelompokan individu atau objek ke dalam beberapa kelompok yang memiliki sifat berbeda antar kelompok, sehingga individu atau objek yang terletak di dalam satu kelompok akan mempunyai sifat relatif homogen. Tujuan analisis cluster adalah mengelompokan objek-objek tersebut[13]. Clustering adalah suatu teknik pengelompokan data dengan cara memisahkan data menjadi beberapa kelompok sesuai dengan karakteristik tertentu yang diinginkan [14], Karena tidak adanya target label kelas untuk setiap data, maka clustering sering disebut juga unsupervised learning [15].

\subsection{Algoritma K-Means}

K-Means merupakan salah satu metode pengelompokan data nonhierarki yang berusaha mempartisi data yang ada ke dalam bentuk dua atau lebih kelompok[16]. K-means adalah salah satu algoritma pembelajaran undirected/unsupervised learning, yang paling sederhana digunakan untuk memecahkan berbagai masalah pengelompokan[17]. Metode K-Means hanya akan bekerja pada atribut numerik karena metode ini merupakan algoritma berbasis jarak dari cara kerjanya membagi data menjadi beberapa cluster[18].

Langkah-langkah dari K-Means clustering [19]:

1. Menentukan banyak k cluster yang ingin dibentuk. Pusat cluster awal (centroid) ditentukan sebarang objek secara random.

2. Menghitung jarak setiap data input terhadap masing-masing centroid menggunakan rumus jarak Eucledian hingga ditemukan jarak yang paling dekat dari setiap data dengan centroid.

Rumus Eucledian Distance:

$$
\sqrt{\sum_{i=1}^{n}\left(x_{i}-y_{i}\right)^{2}}
$$

3. Menghitung nilai centroid baru. Nilai centroid baru diperoleh dari rata-rata cluster yang bersangkutan

4. Menghitung jarak setiap objek dengan tiap centroid yang baru, sama seperti langkah 2.

5. Mengulangi langkah 2 dan 3 sampai tidak ada perubahan anggota cluster. Jika telah terpenuhi, maka nilai ratarata pusat cluster $(\mu \mathrm{j})$ pada iterasi terakhir akan digunakan sebagai parameter untuk menentukan klasifikasi data.

\section{HASIL DAN PEMBAHASAN}

\subsection{Pengolahan Data}

Data pada penelitian ini melalui tahap pra-pemrosesan data sebelum digunakan untuk melakukan proses klasterisasi. Atribut yang dipilih untuk dijadikan acuan dalam proses pengelompokan data yang berhubungan dengan nasabah peminat asuransi PT. Sinar Mas, sampel data 55 orang nasabah dan 3 cluster produk asuransi yaitu 
JURNAL MEDIA INFORMATIKA BUDIDARMA

Volume 5, Nomor 3, Juli 2021, Page 1187-1194

ISSN 2614-5278 (media cetak), ISSN 2548-8368 (media online)

Available Online at https://ejurnal.stmik-budidarma.ac.id/index.php/mib DOI 10.30865/mib.v5i3.3113

asuransi kebakaran, asuransi kecelakaan dan asuransi kesehatan. Berikut ini sampel data laporan jumlah nasabah peminat asuransi.

Tabel 1. Data Laporan Jumlah Nasabah Peminat Asuransi

\begin{tabular}{|c|c|c|c|c|c|}
\hline No. & Inisial & Nama Nasabah & $\begin{array}{c}\text { Asuransi } \\
\text { Kebakaran }\end{array}$ & $\begin{array}{r}\text { Asuransi } \\
\text { Kecelakaan }\end{array}$ & $\begin{array}{c}\text { Asuransi } \\
\text { Kesehatan }\end{array}$ \\
\hline 1 & $\mathrm{P} 1$ & Sari Adelia & 1 & 3 & 2 \\
\hline 2 & $\mathrm{P} 2$ & Fransiska & 1 & 1 & 4 \\
\hline 3 & P3 & Immanuel & 2 & 4 & 5 \\
\hline 4 & P4 & Lisda & 3 & 3 & 1 \\
\hline 5 & P5 & Mhd. Andy & 2 & 1 & 4 \\
\hline 6 & P6 & Rizka & 2 & 2 & 1 \\
\hline 7 & P7 & Amalia & 1 & 1 & 1 \\
\hline 8 & P8 & Muhammad Yuda & 1 & 5 & 3 \\
\hline 9 & P9 & Wahyu & 3 & 5 & 2 \\
\hline 10 & P10 & Novri & 4 & 2 & 3 \\
\hline 11 & P11 & Viktor & 2 & 2 & 2 \\
\hline 12 & $\mathrm{P} 12$ & Winda & 3 & 3 & 1 \\
\hline 13 & P13 & Agung & 4 & 5 & 3 \\
\hline 14 & P14 & Eva santy & 4 & 4 & 2 \\
\hline 15 & P15 & Sarah & 3 & 5 & 5 \\
\hline 16 & P16 & Sherli & 3 & 4 & 5 \\
\hline 17 & P17 & Putri & 1 & 1 & 4 \\
\hline 18 & P18 & Rikardo & 2 & 5 & 5 \\
\hline 19 & P19 & Simon & 5 & 3 & 3 \\
\hline 20 & $\mathrm{P} 20$ & Wahyudi & 2 & 1 & 5 \\
\hline 21 & $\mathrm{P} 21$ & Yulina & 1 & 1 & 4 \\
\hline 22 & $\mathrm{P} 22$ & Andria & 4 & 5 & 5 \\
\hline 23 & $\mathrm{P} 23$ & Adillah & 3 & 4 & 5 \\
\hline 24 & $\mathrm{P} 24$ & Gusti & 1 & 1 & 1 \\
\hline 25 & $\mathrm{P} 25$ & Ikmal & 2 & 5 & 5 \\
\hline 26 & $\mathrm{P} 26$ & Iskandar & 1 & 1 & 1 \\
\hline 27 & $\mathrm{P} 27$ & Johannes & 5 & 5 & 5 \\
\hline 28 & P28 & Rizky Pratiwi & 3 & 1 & 3 \\
\hline 29 & P29 & Muhammad Ali & 2 & 1 & 5 \\
\hline 30 & P30 & Bob Cris & 1 & 2 & 1 \\
\hline 31 & P31 & Lenius & 1 & 1 & 3 \\
\hline 32 & P32 & Novalia & 2 & 5 & 5 \\
\hline 33 & P33 & Andi Prasetyo & 3 & 5 & 5 \\
\hline 34 & P34 & Nursany & 9 & 3 & 2 \\
\hline 35 & P35 & Silvia & 5 & 7 & 8 \\
\hline 36 & P36 & Suci Utari & 2 & 4 & 6 \\
\hline 37 & P37 & Zikri & 3 & 8 & 3 \\
\hline 38 & P38 & Rika Ertiana & 1 & 6 & 1 \\
\hline 39 & P39 & Hasan Siregar & 2 & 5 & 5 \\
\hline 40 & $\mathrm{P} 40$ & Eldini & 5 & 5 & 5 \\
\hline 41 & P41 & May Syarah & 4 & 5 & 5 \\
\hline 42 & $\mathrm{P} 42$ & Perdinan & 3 & 7 & 8 \\
\hline 43 & P43 & Ryan Dwi & 2 & 4 & 6 \\
\hline 44 & P44 & Melina Siregar & 2 & 5 & 5 \\
\hline 45 & $\mathrm{P} 45$ & Yoshi & 3 & 6 & 3 \\
\hline 46 & P46 & Lamlas & 2 & 1 & 5 \\
\hline 47 & P47 & Rumbi & 1 & 3 & 1 \\
\hline 48 & P48 & Dwi Ryan & 4 & 1 & 1 \\
\hline 49 & P49 & Yeremia & 7 & 5 & 5 \\
\hline 50 & P50 & Tigor Ginting & 3 & 5 & 2 \\
\hline 51 & P51 & Bela Sita & 2 & 5 & 5 \\
\hline 52 & P52 & Chandra & 3 & 5 & 3 \\
\hline 53 & P53 & Asri Riana & 7 & 9 & 8 \\
\hline 54 & P54 & Indah Putria & 2 & 4 & 6 \\
\hline 55 & P55 & Irwansyah & 3 & 6 & 6 \\
\hline
\end{tabular}


JURNAL MEDIA INFORMATIKA BUDIDARMA

Volume 5, Nomor 3, Juli 2021, Page 1187-1194

ISSN 2614-5278 (media cetak), ISSN 2548-8368 (media online)

Available Online at https://ejurnal.stmik-budidarma.ac.id/index.php/mib DOI 10.30865/mib.v5i3.3113

\subsection{Penerapan Algoritma K-Means}

Berikut Flowchart algoritma K-Means:

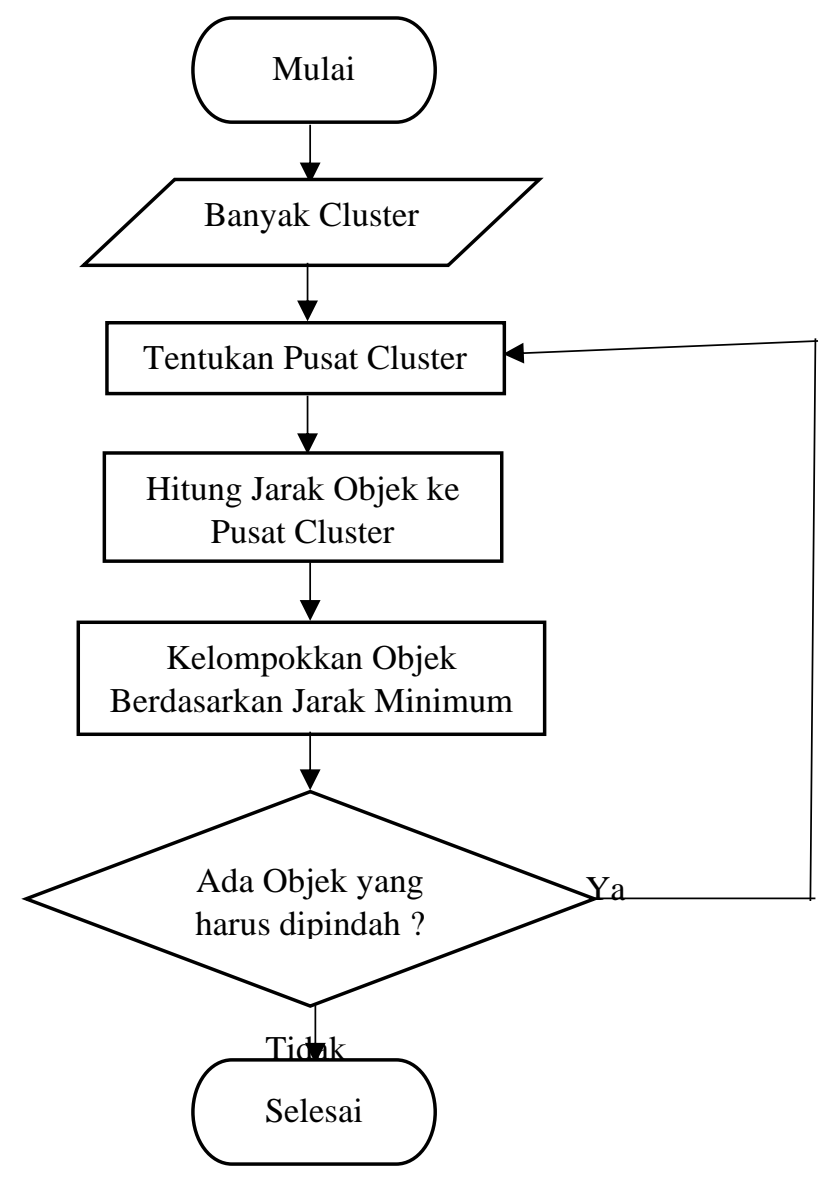

Gambar 1. Flowchart Algortima K-Means

Langkah-langkah pada algoritma $K$-Means.

1. Menentukan jumlah Cluster misalkan sebanyak $k=3$

2. Menentukan Centroid setiap Cluster yang diambil dari data sumber berdasarkan pilihan secara acak atau random

Tabel 2. Data Centroid Awal

\begin{tabular}{ccccc}
\hline Centroid & Nama & $\begin{array}{c}\text { Asuransi } \\
\text { Kebakaran }\end{array}$ & $\begin{array}{c}\text { Asuransi } \\
\text { Kecelakaan }\end{array}$ & $\begin{array}{c}\text { Asuransi } \\
\text { Kesehatan }\end{array}$ \\
\hline$M 1$ & Asri Riana (P7) & 1 & 1 & 1 \\
$M 2$ & Silvia (P35) & 5 & 7 & 8 \\
$M 3$ & Sari Adelia (P53) & 7 & 9 & 8 \\
\hline
\end{tabular}

3. Hitung jarak data ke Centroid menggunakan persamaan 1, data tersebut dari Cluster terdekatnya. Cluster 1:

a. Jarak antara Nasabah nomor pertama (P1) dengan titik M1

$$
=\sqrt{(1-1)^{2}+(3-1)^{2}+(2-1)^{2}}=2,236
$$

b. Jarak antara Nasabah nomor kedua (P2) dengan titik M1

$$
=\sqrt{(1-1)^{2}+(1-1)^{2}+(4-1)^{2}}=3
$$

c. Jarak antara Nasabah nomor ketiga (P3) dengan titik M1

$$
=\sqrt{(2-1)^{2}+(4-1)^{2}+(5-1)^{2}}=5,099
$$

Cluster 2:

a. Jarak antara Nasabah nomor pertama (P1) dengan titik M2 
JURNAL MEDIA INFORMATIKA BUDIDARMA

Volume 5, Nomor 3, Juli 2021, Page 1187-1194

ISSN 2614-5278 (media cetak), ISSN 2548-8368 (media online)

Available Online at https://ejurnal.stmik-budidarma.ac.id/index.php/mib DOI 10.30865/mib.v5i3.3113

$$
=\sqrt{(1-5)^{2}+(3-7)^{2}+(2-8)^{2}}=8,246
$$

b. Jarak antara Nasabah nomor kedua (P2) dengan titik M2

$$
=\sqrt{(1-5)^{2}+(1-7)^{2}+(4-8)^{2}}=8,246
$$

c. Jarak antara Nasabah nomor ketiga (P3) dengan titik M2

$$
=\sqrt{(2-5)^{2}+(4-7)^{2}+(5-8)^{2}}=5,196
$$

Cluster 3:

a. Jarak antara Nasabah nomor pertama (P1) dengan titik M3

$$
=\sqrt{(1-7)^{2}+(3-9)^{2}+(2-8)^{2}}=10,392
$$

b. Jarak antara Nasabah nomor kedua (P2) dengan titik M3

$$
=\sqrt{(1-7)^{2}+(1-9)^{2}+(4-8)^{2}}=10,770
$$

c. Jarak antara Nasabah nomor ketiga (P3) dengan titik M3

\begin{tabular}{|c|c|c|c|c|c|c|c|}
\hline No & Inisial & $\mathrm{C} 1$ & $\mathrm{C} 2$ & C3 & $\begin{array}{c}\text { Jarak } \\
\text { Terdekat }\end{array}$ & $\begin{array}{c}\text { Jarak Centroid } \\
\text { Terkecil }\end{array}$ & Hasil Kuadrat \\
\hline 1 & $\mathrm{P} 1$ & 2,236 & 8,246 & 10,392 & $\mathrm{C} 1$ & 2,236 & 5 \\
\hline 2 & $\mathrm{P} 2$ & 3,000 & 8,246 & 10,770 & $\mathrm{C} 1$ & 3,000 & 9 \\
\hline 3 & P3 & 5,099 & 5,196 & 7,681 & $\mathrm{C} 1$ & 5,099 & 26 \\
\hline 4 & P4 & 2,828 & 8,307 & 10,050 & $\mathrm{C} 1$ & 2,828 & 8 \\
\hline 5 & P5 & 3,162 & 7,810 & 10,247 & $\mathrm{C} 1$ & 3,162 & 10 \\
\hline 6 & P6 & 1,414 & 9,110 & 11,091 & $\mathrm{C} 1$ & 1,414 & 2 \\
\hline 7 & $\mathrm{P} 7$ & 0,000 & 10,050 & 12,207 & $\mathrm{C} 1$ & 0,000 & 0 \\
\hline 8 & P8 & 4,472 & 6,708 & 8,775 & $\mathrm{C} 1$ & 4,472 & 20 \\
\hline 9 & P9 & 4,583 & 6,633 & 8,246 & $\mathrm{C} 1$ & 4,583 & 21 \\
\hline 10 & P10 & 3,742 & 7,141 & 9,110 & $\mathrm{C} 1$ & 3,742 & 14 \\
\hline 11 & P11 & 1,732 & 8,367 & 10,488 & $\mathrm{C} 1$ & 1,732 & 3 \\
\hline 12 & P12 & 2,828 & 8,307 & 10,050 & C1 & 2,828 & 8 \\
\hline 13 & P13 & 5,385 & 5,477 & 7,071 & $\mathrm{C} 1$ & 5,385 & 29 \\
\hline 14 & P14 & 4,359 & 6,782 & 8,367 & $\mathrm{C} 1$ & 4,359 & 19 \\
\hline 15 & P15 & 6,000 & 4,123 & 6,403 & $\mathrm{C} 2$ & 4,123 & 17 \\
\hline 16 & P16 & 5,385 & 4,690 & 7,071 & $\mathrm{C} 2$ & 4,690 & 22 \\
\hline 17 & P17 & 3,000 & 8,246 & 10,770 & $\mathrm{C} 1$ & 3,000 & 9 \\
\hline 18 & P18 & 5,745 & 4,690 & 7,071 & $\mathrm{C} 2$ & 4,690 & 22 \\
\hline 19 & P19 & 4,899 & 6,403 & 8,062 & $\mathrm{C} 1$ & 4,899 & 24 \\
\hline 20 & $\mathrm{P} 20$ & 4,123 & 7,348 & 9,899 & $\mathrm{C} 1$ & 4,123 & 17 \\
\hline 21 & $\mathrm{P} 21$ & 3,000 & 8,246 & 10,770 & $\mathrm{C} 1$ & 3,000 & 9 \\
\hline 22 & $\mathrm{P} 22$ & 6,403 & 3,742 & 5,831 & $\mathrm{C} 2$ & 3,742 & 14 \\
\hline 23 & $\mathrm{P} 23$ & 5,385 & 4,690 & 7,071 & $\mathrm{C} 2$ & 4,690 & 22 \\
\hline 24 & $\mathrm{P} 24$ & 0,000 & 10,050 & 12,207 & $\mathrm{C} 1$ & 0,000 & 0 \\
\hline 25 & $\mathrm{P} 25$ & 5,745 & 4,690 & 7,071 & $\mathrm{C} 2$ & 4,690 & 22 \\
\hline 26 & P26 & 0,000 & 10,050 & 12,207 & $\mathrm{C} 1$ & 0,000 & 0 \\
\hline 27 & $\mathrm{P} 27$ & 6,928 & 3,606 & 5,385 & $\mathrm{C} 2$ & 3,606 & 13 \\
\hline 28 & P28 & 2,828 & 8,062 & 10,247 & $\mathrm{C} 1$ & 2,828 & 8 \\
\hline 29 & P29 & 4,123 & 7,348 & 9,899 & $\mathrm{C} 1$ & 4,123 & 17 \\
\hline 30 & P30 & 1,000 & 9,487 & 11,576 & $\mathrm{C} 1$ & 1,000 & 1 \\
\hline 31 & P31 & 2,000 & 8,775 & 11,180 & $\mathrm{C} 1$ & 2,000 & 4 \\
\hline 32 & P32 & 5,745 & 4,690 & 7,071 & $\mathrm{C} 2$ & 4,690 & 22 \\
\hline 33 & P33 & 6,000 & 4,123 & 6,403 & $\mathrm{C} 2$ & 4,123 & 17 \\
\hline 34 & P34 & 8,307 & 8,246 & 8,718 & $\mathrm{C} 2$ & 8,246 & 68 \\
\hline 35 & P35 & 10,050 & 0,000 & 2,828 & $\mathrm{C} 2$ & 0,000 & 0 \\
\hline 36 & P36 & 5,916 & 4,690 & 7,348 & $\mathrm{C} 2$ & 4,690 & 22 \\
\hline 37 & P37 & 7,550 & 5,477 & 6,481 & $\mathrm{C} 2$ & 5,477 & 30 \\
\hline
\end{tabular}

$=\sqrt{(2-7)^{2}+(4-9)^{2}+(5-8)^{2}}=7,681$

Dan seterusnya dilakukan perhitungan jarak sampai data ke-55 dengan rumus seperti di atas. Untuk lebih lengkapnya jarak pada setiap baris data, hasilnya seperti pada tabel berikut:

Tabel 3. Hasil Rekapitulasi Perhitungan Iterasi Ke 1 
ISSN 2614-5278 (media cetak), ISSN 2548-8368 (media online)

Available Online at https://ejurnal.stmik-budidarma.ac.id/index.php/mib DOI 10.30865/mib.v5i3.3113

\begin{tabular}{|c|c|c|c|c|c|c|c|}
\hline No & Inisial & $\mathrm{C} 1$ & $\mathrm{C} 2$ & $\mathrm{C} 3$ & $\begin{array}{c}\text { Jarak } \\
\text { Terdekat }\end{array}$ & $\begin{array}{c}\text { Jarak Centroid } \\
\text { Terkecil }\end{array}$ & Hasil Kuadrat \\
\hline 38 & P38 & 5,000 & 8,124 & 9,695 & $\mathrm{C} 1$ & 5,000 & 25 \\
\hline 39 & P39 & 5,745 & 4,690 & 7,071 & $\mathrm{C} 2$ & 4,690 & 22 \\
\hline 40 & $\mathrm{P} 40$ & 6,928 & 3,606 & 5,385 & $\mathrm{C} 2$ & 3,606 & 13 \\
\hline 41 & $\mathrm{P} 41$ & 6,403 & 3,742 & 5,831 & $\mathrm{C} 2$ & 3,742 & 14 \\
\hline 42 & $\mathrm{P} 42$ & 9,434 & 2,000 & 4,472 & $\mathrm{C} 2$ & 2,000 & 4 \\
\hline 43 & $\mathrm{P} 43$ & 5,916 & 4,690 & 7,348 & $\mathrm{C} 2$ & 4,690 & 22 \\
\hline 44 & P44 & 5,745 & 4,690 & 7,071 & $\mathrm{C} 2$ & 4,690 & 22 \\
\hline 45 & $\mathrm{P} 45$ & 5,745 & 5,477 & 7,071 & $\mathrm{C} 2$ & 5,477 & 30 \\
\hline 46 & $\mathrm{P} 46$ & 4,123 & 7,348 & 9,899 & $\mathrm{C} 1$ & 4,123 & 17 \\
\hline 47 & $\mathrm{P} 47$ & 2,000 & 9,000 & 11,000 & $\mathrm{C} 1$ & 2,000 & 4 \\
\hline 48 & P48 & 3,000 & 9,274 & 11,045 & $\mathrm{C} 1$ & 3,000 & 9 \\
\hline 49 & P49 & 8,246 & 4,123 & 5,000 & $\mathrm{C} 2$ & 4,123 & 17 \\
\hline 50 & P50 & 4,583 & 6,633 & 8,246 & $\mathrm{C} 1$ & 4,583 & 21 \\
\hline 51 & P51 & 5,745 & 4,690 & 7,071 & $\mathrm{C} 2$ & 4,690 & 22 \\
\hline 52 & P52 & 4,899 & 5,745 & 7,550 & $\mathrm{C} 1$ & 4,899 & 24 \\
\hline 53 & P53 & 12,207 & 2,828 & 0,000 & C3 & 0,000 & 0 \\
\hline 54 & P54 & 5,916 & 4,690 & 7,348 & $\mathrm{C} 2$ & 4,690 & 22 \\
\hline \multirow[t]{3}{*}{55} & P55 & 7,348 & 3,000 & 5,385 & $\mathrm{C} 2$ & 3,000 & 9 \\
\hline & & & WCV & & & & 851 \\
\hline & & BESAR & RASIO & & & 0,029 & \\
\hline
\end{tabular}

4. Hitung nilai WCV (Within Cluster Variation) dengan memangkatkan jarak terdekat cluster dan menjumlahkan setiap nilai $W C V$.

$$
\begin{aligned}
& W C V=2,236^{2}+3^{2}+5,099^{2}+\ldots \ldots \ldots .+3^{2} \\
& W C V=851
\end{aligned}
$$

5. Hitung nilai $B C V$ (Between Cluster Variation) dengan cara menjumlahkan hasil dari jarak diantara setiap centroid.

$$
\text { a. } \begin{aligned}
d(\mathrm{~m} 1, \mathrm{~m} 2)=\sqrt{(m 1-m 2)^{2}} \\
\quad=\sqrt{(1-5)^{2}+(1-7)^{2}+(1-8)^{2}}=10,050
\end{aligned}
$$

b. $d(\mathrm{~m} 1, \mathrm{~m} 3)=\sqrt{(m 1-m 3)^{2}}$

$$
=\sqrt{(1-7)^{2}+(1-9)^{2}+(1-8)^{2}}=12,207
$$

c. $d(\mathrm{~m} 2, \mathrm{~m} 3)=\sqrt{(m 2-m 3)^{2}}$

$$
=\sqrt{(5-7)^{2}+(7-9)^{2}+(8-8)^{2}}=2,828
$$

Nilai $B C V=d(\mathrm{~m} 1, \mathrm{~m} 2)+d(\mathrm{~m} 1, \mathrm{~m} 3)+d(\mathrm{~m} 2, \mathrm{~m} 3)$

$$
=10,050+12,207+2,828=25,085
$$

6. Menghitung nilai besar rasio dengan membandingkan nilai $B C V$ dan $W C V$

Rasio $=B C V / W C V$

$$
=25,085 / 851=0,029
$$

Berdasarkan hasil perhitungan jarak variabel pada centroid awal maka masing-masing cluster memiliki anggota sebagai berikut yaitu :

a. Cluster 1 mempunyai jumlah anggota sebanyak 30 orang

b. Cluster 2 mempunyai jumlah anggota sebanyak 24 orang

c. Cluster 3 mempunyai jumlah anggota sebanyak 1 orang

Dari perhitungan dengan sampel data 55 orang nasabah didapatkan 3 cluster yaitu cluster 1 untuk asuransi kebakaran mempunyai jumlah anggota sebanyak 30 orang, cluster 2 untuk asuransi kecelakaan mempunyai jumlah anggota sebanyak 24 orang, cluster 3 untuk asuransi kesehatan mempunyai jumlah anggota sebanyak 1 orang.

\section{KESIMPULAN}

Berdasarkan perhitungan data yang sudah dilakukan dengan menggunakan metode $K$-Means diperoleh 3 cluster dari keseluruhan data, yaitu cluster 1 untuk asuransi kebakaran mempunyai jumlah anggota sebanyak 30 orang, cluster 2 untuk asuransi kecelakaan mempunyai jumlah anggota sebanyak 24 orang, cluster 3 untuk asuransi kesehatan mempunyai jumlah anggota sebanyak 1 orang. Pada hasil akhir terlihat jelas semua data memiliki 
ISSN 2614-5278 (media cetak), ISSN 2548-8368 (media online)

Available Online at https://ejurnal.stmik-budidarma.ac.id/index.php/mib DOI 10.30865/mib.v5i3.3113

kedekatan yang sama antara satu dengan lainnya sehingga terbentuk satu pengelompokan berdasarkan jarak kedekatan dengan nilai data. Dengan demikian maka pembentukan cluster yang optimal dalam klasterisasi produk asuransi adalah menggunakan metode K-Means.

\section{UCAPAN TERIMAKASIH}

Terima kasih disampaikan kepada STMIK Triguna Dharma dan pihak-pihak yang telah mendukung terlaksananya penelitian ini.

\section{REFERENCES}

[1] A. Khairani and I. Irwansyah, "Pemanfaatan Big Data Untuk Percepatan Proses Underwriting Sebagai Strategi Komunikasi Marketing Terpadu Perusahaan Asuransi Jiwa," J. Nomosleca, vol. 4, no. 2, 2018, doi: 10.26905/nomosleca.v4i2.2546.

[2] A. Apriliani Akhadun and A. Hidayat, "Sistem Pendukung Keputusan Pemilihan Produk Asuransi Berbasis Web menggunakan Metode AHP (Analytic Hierarchy Process ) Studi Kasus BRI Life Semarang," J. Inform. dan Rekayasa Perangkat Lunak, vol. 2, no. 1, p. 49, 2020, doi: 10.36499/jinrpl.v2i1.3210.

[3] B. Sinaga, Sulindawaty, and I. Siagian, "Sistem Pendukung Keputusan Pemilihan Asuransi Dengan Metode Weighted Product Dan Weighted Sum Model Pada PT. Prudential," J. Mantik Penusa, vol. 1, no. 2, pp. 59-64, 2017, [Online]. Available: http://e-jurnal.pelitanusantara.ac.id/index.php/mantik/article/view/267/166.

[4] L. M. Pratiwi, Diana, and E. P. Agustin, "Penerapan K-Means Clustering Untuk Memprediksi Minat Nasabah Pada Pt . Asuransi Jiwa Bersama 1912 Bumiputera Prabumulih," Univ. Bina Darma, pp. 1-16, 2016.

[5] S. N. Gama, I. Cholissodin, and M. T. Furqon, "Clustering Portal Jurnal International untuk Rekomensari Publikasi Berdasarkan Kualitas Cluster Menggunakan Kernel K-Means,” Progr. Teknol. Inf. dan Ilmu Komput. Univ. Brawijaya, vol. 5, no. 1, 2015.

[6] S. S. Nagari and L. Inayati, "Implementation of Clustering Using K-Means Method To Determine Nutritional Status," $J$. Biometrika dan Kependud., vol. 9, no. 1, p. 62, 2020, doi: 10.20473/jbk.v9i1.2020.62-68.

[7] R. NOVIANTO, "Penerapan Data Mining menggunakan Algoritma K-Means Clustering untuk Menganalisa Bisnis Perusahaan Asuransi," JATISI (Jurnal Tek. Inform. dan Sist. Informasi), vol. 6, no. 1, pp. 85-95, 2019, doi: 10.35957/jatisi.v6i1.150.

[8] W. S. Prasetya, "Sistem Pendukung Keputusan Pemilihan Produk Asuransi," vol. 8, no. 1, pp. 105-116, 2018.

[9] Y. Irawan, "Penerapan data mining untuk evaluasi data penjualan menggunakan metode clustering dan algoritma hirarki divisive," Jtiulm, vol. 3, no. 1, pp. 13-20, 2019.

[10] A. H. Nasyuha et al., "Frequent pattern growth algorithm for maximizing display items," Telkomnika (Telecommunication Comput. Electron. Control., vol. 19, no. 2, pp. 390-396, 2021, doi: 10.12928/TELKOMNIKA.v19i2.16192.

[11] S. Suliman, "Implementasi Data Mining Terhadap Prestasi Belajar Mahasiswa Berdasarkan Pergaulan dan Sosial Ekonomi Dengan Algoritma K-Means Clustering,” Simkom, vol. 6, no. 1, pp. 1-11, 2021, doi: 10.51717/simkom.v6i1.48.

[12] Yuda Irawan, "Implementation Of Data Mining For Determining Majors Using K-Means Algorithm In Students Of SMA Negeri 1 Pangkalan Kerinci," J. Appl. Eng. Technol. Sci., vol. 1, no. 1, pp. 17-29, 2019, doi: 10.37385/jaets.v1i1.18.

[13] M. W. Talakua, Z. A. Leleury, and A. W. Talluta, "Acluster Analysis By Using K-Means Method for Grouping of District/City in Maluku Province Industrial Based on Indicators of Maluku Development Index in 2014," Barekeng J. Ilmu Mat. dan Terap., vol. 11, no. 2, pp. 119-128, 2017.

[14] R. R. Putra and C. Wadisman, "Implementasi Data Mining Pemilihan Pelanggan Potensial Menggunakan Algoritma K Means," INTECOMS J. Inf. Technol. Comput. Sci., vol. 1, no. 1, pp. 72-77, 2018, doi: 10.31539/intecoms.v1i1.141.

[15] Y. Lase and E. Panggabean, "Implementasi Metode K-Means Clustering Dalam Sistem Pemilihan Jurusan Di SMK Swasta Harapan Baru," J. Teknol. dan Ilmu Komput. Prima, vol. 2, no. 2, p. 43, 2019, doi: 10.34012/jutikomp.v2i2.723.

[16] L. Maulida, "Penerapan Datamining Dalam Mengelompokkan Kunjungan Wisatawan Ke Objek Wisata Unggulan Di Prov. Dki Jakarta Dengan K-Means," JISKA (Jurnal Inform. Sunan Kalijaga), vol. 2, no. 3, p. 167, 2018, doi: 10.14421/jiska.2018.23-06.

[17] A. V. D. Sano and H. Nindito, "Application of K-Means Algorithm for Cluster Analysis on Poverty of Provinces in Indonesia," ComTech Comput. Math. Eng. Appl., vol. 7, no. 2, p. 141, 2016, doi: 10.21512/comtech.v7i2.2254.

[18] A. Bastian, H. Sujadi, and G. Febrianto, "Penerapan Algoritma K-Means Clustering Analysis Pada Penyakit Menular Manusia (Studi Kasus Kabupaten Majalengka)," no. 1, pp. 26-32.

[19] A. Mahmudan, "Clustering of District or City in Central Java Based COVID-19 Case Using K-Means Clustering," $J$. Mat. Stat. dan Komputasi, vol. 17, no. 1, pp. 1-13, 2020, doi: 10.20956/jmsk.v17i1.10727. 